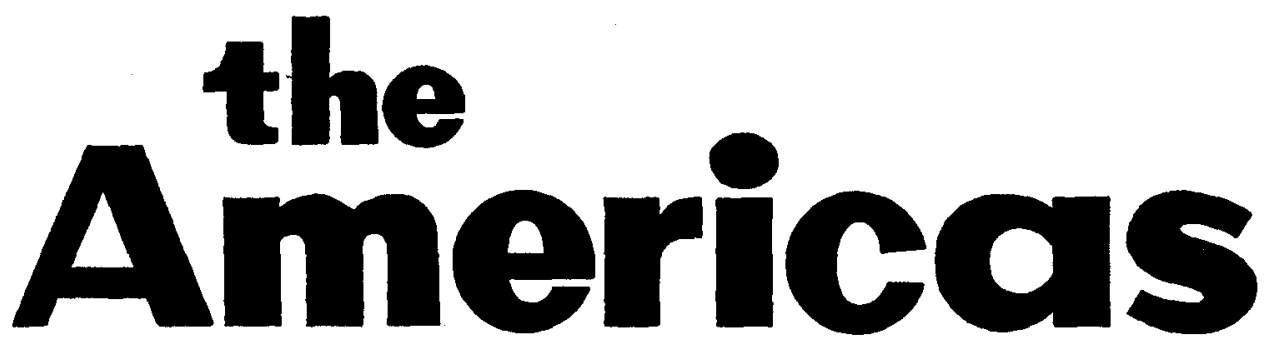

A QUARTERLY REVIEW OF INTER-AMERICAN CULTURAL HISTORY

Indian Congregations in the New Kingdom of Granada: Land Tenure Aspects, 1595-1850... Orlando Fals-Borda 331

Thoughts on Church Architecture in Mexico

Gordon Bodenwein

Public Work and Social Welfare in Colonial Spanish American Towns................Fredrick B. Pike 361

The Franciscan Province of the Holy Cross of Española, 1505-1559...................Antonine S. Tibesar

\title{
DOCUMENTS
}

Constitutions of the Franciscan Province of the Holy Cross in Española (1538-1540)

(Ed.) Antonine S. Tibesar 391

INTER-AMERICAN NOTES................. 398

BOOK REVIEWS........................ 406

(Listed on inside front cover)

\section{Copyright, 1957}

\section{ACADEMY OF AMERICAN FRANCISCAN HISTORY}

The contents of THE AMERICAS are indexed in the Catbolic Periodical Index and the International Index to Periodicals, and abstracted in Historical Abstracts.

Suggested abbreviation: $T A m$ 


\title{
EDITORIAL STAFF
}

\author{
Mathias C. Kiemen, O.F.M. \\ Managing Editor \\ Bede A. Dauphinee, O.F.M. \\ Assistant Managing Editor \\ JANE Herrick \\ Editorial Assistant \\ Francis B. Steck, O.F. M. \\ Quincy College \\ Maynard Geiger, O.F.M. \\ Santa Barbara, California \\ Lázaro Lamadrid, O. F. M. \\ Washington, D.C. \\ Fidel Chauvet, O.F.M. \\ Mexico City, D.F. \\ Lino G. Canedo, O.F. M. \\ Washington, D.C. \\ Michael B. McCloskey, O.F.M. \\ Siena College

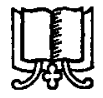

\section{ADVISORY EDITORS}

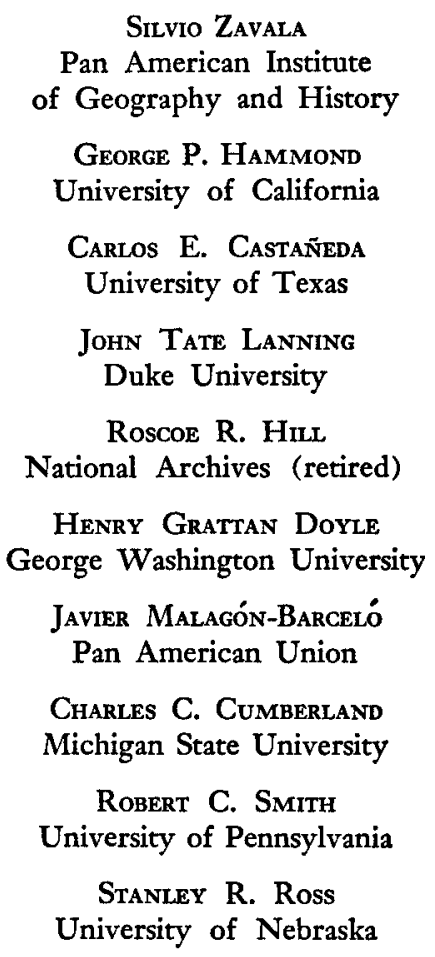

John P. Harrison

Rockefeller Foundation

Robert S. Chamberlain

Carnegie Institution of Washington

Ruth Lapham Butler

Newberry Library, Chicago

J. Manuel Espinosa

Department of State, Washington, D.C.

Manoel Cardozo

Catholic University of America

Donald C. Cutter

University of Southern California

Charles J. Bishko

University of Virginia

Philip Wayne Powell

University of California at Santa Barbara

A. L. Burt

University of Minnesota

ERNEST J. BurRus, S.J. Institutum Historicum S.J., Rome

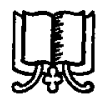

THE AMERICAS is published in July, October, January, and April; annual subscription United States and Canada $\$ 6.00$; all other countries $\$ 4.00$. Address all communications to the Managing Editor, $5401 \mathrm{~W}$. Cedar Lane, Washington 14, D.C. Opinions expressed are the responsibility of contributors.

Second-class mail privileges autborized at Washington, D.C., and Baltimore, Maryland. 